\title{
Open-air treatment of wastewater from land-based marine fish farms in extensive and intensive systems: current technology and future perspectives
}

\author{
Jérôme Hussenot ${ }^{(1 *)}$, Sébastien Lefebvre ${ }^{(1)}$, Nicolas Brossard \\ (1) Centre de recherche en écologie marine et aquaculture (CNRS-Ifremer), BP 5, 17137 L'Houmeau, France. \\ (2) present address: Bureau veritas, centre pêche-aquaculture, 5 mee F.-Toullec, 56100 Lorient, France.
}

Received December 4, 1997; accepted February 11, 1998.

\begin{abstract}
Marine land-based fish farms located in coastal wetlands (salt-pond zones, lagoon banks, etc.), whether extensive or intensive, send farm effluents directly to the sea or after short periods of stocking in retention reservoirs. The aims of our investigation have been to compare the efficiency of current and potential water treatment procedures in open-air. Wastewater retention ponds in commercial farms (Atlantic coasts of France) are efficient in removing up to 1 metric ton of particulate material (dry weight) per hectare and per day (faeces and unconsumed feed), but are inefficient in reducing dissolved wastes, both organic (urea, amino acids, protein) and inorganic (total ammonia nitrogen, phosphates). Forthcoming outdoor technology to treat these forms of waste were examined by trials at different sites: treatment by foam fractionation in extensive systems (Italian fish pond culture), treatment by microalgae production (Skeletonema costatum) and oyster filtration (Crassostrea gigas) in intensive systems (sea bass farm, Dicentrarchus labrax). It can be concluded that foam fractionation coupled with aeration and water circulation is a good way to treat and recirculate wastewaters in extensive systems, but that a multiple treatment combining a retention pond, foam fractionation and microalgae-bivalve filtration, is the best solution to treat all these forms of wastes from intensive systems. (C) Ifremer/ Elsevier, Paris
\end{abstract}

Water treatment / effluent / aquaculture / sedimentation / foam fractionation / microalgae / oyster

Résumé - Traitement en bassins extérieurs des eaux usées d'installations piscicoles marines à terre, en élevage intensif comme extensif : technologies actuelles et perspectives. Les fermes d'élevage de poissons marins, en intensif comme en extensif, situées en zones littorales humides (de marais salants, de bordures de lagunes, etc.), rejettent leurs effluents, directement en mer ou après une courte période de rétention en bassins de lagunage. Le but de notre recherche est de comparer les performances de différentes techniques de traitement en plein-air des effluents, aussi bien classiques que novatrices. Les bassins de lagunage des eaux usées mis en place dans les fermes de production (côte atlantique française) permettent d'éliminer jusqu'à 1 tonne de matière particulaire (poids sec) par hectare et par jour (fèces et aliment non consommé), mais sont inefficaces pour éliminer les déchets de forme dissoute, aussi bien organiques (urée, acides aminés, protéines) que minéraux (azote ammoniacal total, phosphates). Des tests d'efficacité de nouvelles techniques de traitement en extérieur ont été effectués sur différents sites : un traitement par écumage sur des systèmes d'élevage extensif (valliculture italienne), un traitement par production microalgale (Skeletonema costatum) suivie d'une filtration par des huîtres (Crassostrea gigas) en sytème d'élevage intensif (ferme marine de bar, Dicentrarchus labrax). Ainsi, l'écumage couplé avec une aération et une circulation de l'eau, est un moyen de traitement satisfaisant pour le traitement et le système de circulation des eaux des fermes d'élevage extensif de poissons marins; mais un traitement multiple, combinant lagunage, écumage et filtration microalgue-bivalve, est nécessaire pour un traitement efficace de toutes les formes de déchets des élevages intensifs de poissons marins. (C) Ifremer/Elsevier, Paris

Traitement de l'eau / effluent / décantation / sédimentation / écumage / microalgue / huître

\section{INTRODUCTION}

Land-based marine fish farms are characterized by huge amounts of seawater passing through the fishponds [11]. In French coastal wetlands [10], two types of problems may arise from such a situation: (i) the water accessibility can be limited by tide levels (Atlantic coast) or water quality (estuaries, lagoons); and (ii) the impact of effluents both on the outside environment and the fish farm itself $[1,16]$. This awareness has led

\footnotetext{
* Corresponding author, e-mail: jhusseno@ifremer.fr
} 
to much attention and concern, resulting in the introduction of regulations and water quality criteria [17].

Water treatment equipment (mechanical filters, pressurized biological filters) marketed by aquaculture engineering companies [24, 27] are designed principally for farm units using indoor fish tanks or limited water flow $\left(500-1000 \mathrm{~m}^{3} \cdot \mathrm{h}^{-1}\right)$. According to Van Rijn [25], who has described the most common water purification treatments in intensive systems, few studies on mass treatment or recirculating systems using earthen ponds or reservoirs have been conducted.

In this context, the aims of our investigation were to compare the efficiency of water treatment procedures potentially operable in outdoor systems to treat extensive or intensive aquaculture effluents before discharge or recycling. The most simple technique currently being used to treat before discharge consists of building a waste retention pond at the outlet of the fish rearing facility [15]. Many farms stock effluents in reservoirs before allowing them to drain into the sea, but treatment efficiency and hydraulic characteristics of these reservoirs are rarely studied. In the present work, (i) we compare removal of particulate and dissolved Inaterial from two wastewater retention lagoons located in private farms and (ii) we examined, at an experimental level, what kind of additional outdoor treatment systems could be developed. Foam fractionation $[6,23,26,28]$, microalgal production $[7,13]$, bivalve filtration [18-21] were studied as forthcoming technologies suitable for coastal wetland aquaculture, where, usually, large marsh areas are unoccupied around fish production ponds.

\section{MATERIAL AND METHODS}

\subsection{Treatment by wastewater retention lagoon}

For two years (1995-1996), we studied the quality of inlet and outlet water from the waste retention lagoons functioning in each of two private fish farms, both located on Rê island (Charente-Maritime, Atlantic coast of France). Both the hydraulic systems (variable level in farm 1 and constant level in farm 2) and the retention times (table $I$ ) of the two lagoons are different. In farm 1 (100 metric tons of turbot: Psetta maxima), the water temperatures are corrected, in winter and summer, mixing borehole water and seawater (table I). The water flow and the lagoon retention time vary with sea level and the periodic opening of an automatic outlet sluice. By this process, the lagoons are completely dried out every $12 \mathrm{~h}$. In farm 2 (300400 metric tons of seabass: Dicentrarchus labrax), the production has been increasing during these two years, requiring a water flow increase in the second year. We werc able to study the effects of different lagoon retention times on the removal efficiency of soluble and particulate water compounds. To calculate with precision the retention times, the cubic capacity of the lagoons
Table I. Wastewater retention Jagoon characteristics, water flow through, and fish production in the two farms, summer 1996.

\begin{tabular}{lcc}
\hline Fish farm & Farm 1 & Farm 2 \\
\hline Waste retention lagoon type & & \\
Water level & variable & constant \\
Maximum volume $\left(\mathrm{m}^{3}\right)$ & 10000 & 85000 \\
Retention time (hours) & 4 to 8 & 13 \\
Water llow & 1000 & 6500 \\
Seawater $\left(\mathrm{m}^{3} \cdot \mathrm{h}^{-1}\right)$ & $1: 3$ & by exchange \\
Borehole water (vol: : total volume) & & \\
Fish farm & turbot & seabass \\
Species & 100 & 400 \\
Mean hinmass (metric tons) & 1 & 5 \\
Daily feeding (tons of pellets) & & \\
\hline
\end{tabular}

was determined, using depth profiles and aerial photography of the water surfaces.

In farm 1, the particular discharge system of the wastewater retention lagoon required water sampling at the lagoon outlet every $20 \mathrm{~min}$ during draining periods. Two sampling campaigns were carried out (May 29-30 and July 11-12). Earlier work on farm 2 [9] had demonstrated that sampling at $14: 00 \mathrm{~h}$ (time zone GMT $+2 \mathrm{~h}$; longitude $2^{\circ} \mathrm{W}$ ) gave a correct estimate of the values occurring during a $24-\mathrm{h}$ cycle. Temperature, $\mathrm{pH}$, dissolved oxygen and salinity were measured by field electronic equipment (oxymeter 196 WTW Inc., Weilheim, Germany; pHmeter 752 Knick, Berlin, Germany; conductimeter 196 WTW Inc., Weilheim, Germany). Water samples were filtered through glassfibre filters (Whatman GF/C) to separate particulate material (TSS: total suspended solids, VSS: volatile suspended solids) from soluble material. Filters were immediately placed in a drying oven $\left(60^{\circ} \mathrm{C}\right)$ and the filtered water samples were transported $\left(+5^{\circ} \mathrm{C}\right.$ dark box) to a field laboratory for later analysis of nutrients (TAN: total ammonia nitrogen, nitrites, nitrates, phosphates) by autoanalyser (Skalar Inc., Breda, The Netherlands) after storage at $-18{ }^{\circ} \mathrm{C}$ [22].

\subsection{Treatment by foam fractionation}

An acration and foam fractionation system was developed in Italy, in an extensive aquaculture facility (Valle Figheri, Padova. Italy) to solve water quality problems caused by the closed circulation during summer. Venice lagoon waters, near fish pond culture sites, are intensely polluted by industrial contaminants in summer. To determine the precise efficiencies of water treatments, a foam fractionation apparatus (FFA) was studied in October 1996, at the inlet sluice of a fish pond in the semi-intensive zone of Valle Figheri (figure 1). FFA is used in this zone to establish a renewal (air-lift system), an oxygenation (air diffusers) and a treatment (foam condensate extraction) of water. A closed recirculation system was developed between the pond $\left(1500 \mathrm{~m}^{2}\right)$ and an extensive lagoon (300 ha). Under these conditions, the air-lift pump produced a water flow of $250 \mathrm{~m}^{3} \cdot \mathrm{h}^{-1}$, that crossed the FFA. Microbubbles were produced by two 1-m 


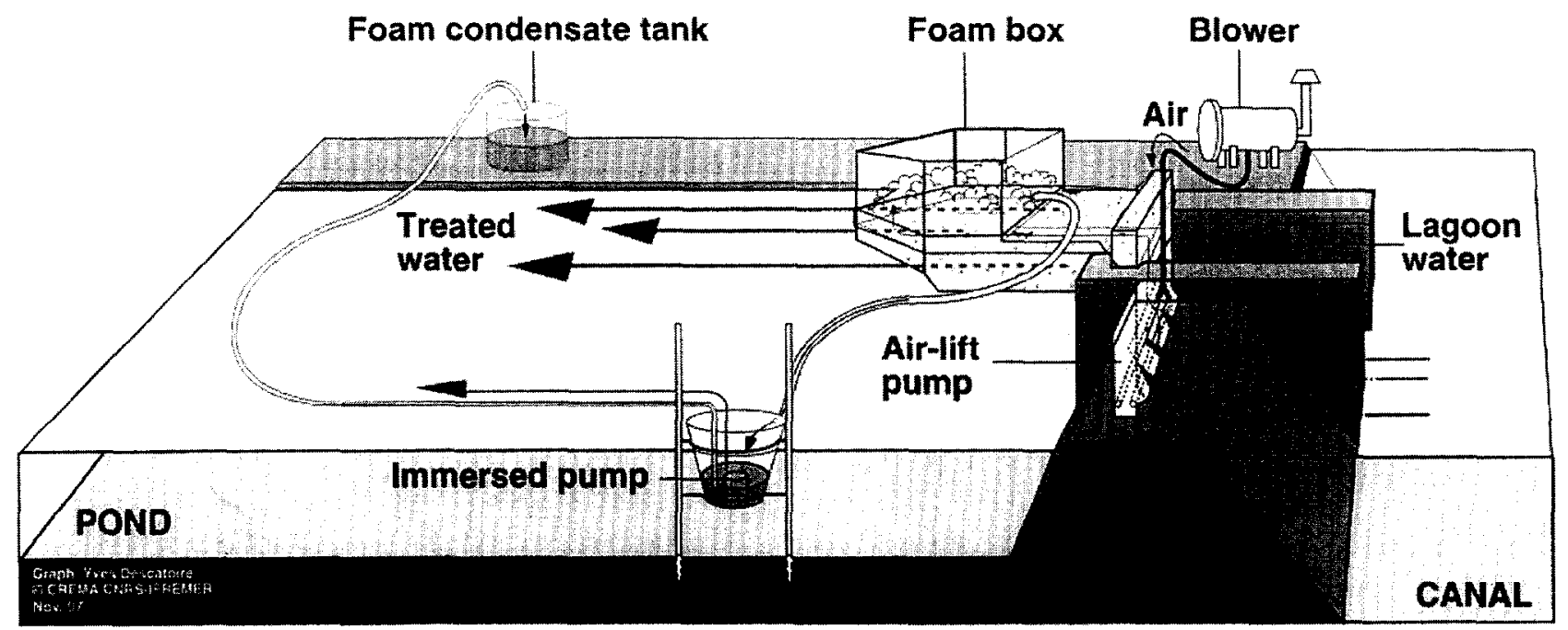

Figure 1. View of the foam fractionation apparatus (FFA), located at the inlet of a semi-intensive fish-pond, used as air-lift pump coupled with a treatment by aeration and foam fractionation. The fish-pond uses recycling waters coming from extensive zones of the valliculture (graph: Y. Descatoire, Crema, 1997).

ceramic diffusers (pore size $60 \mu \mathrm{m}$ ) connected to a blower $(1100 \mathrm{~W})$, delivering $70 \mathrm{~m}^{3}$ air $\mathrm{h}^{-1}$ at a depth of $1 \mathrm{~m}$. An automatic immersed pump was used to transfer foam condensates into tanks located on the dike.

Inlet water and foam condensates were sampled ( 2 samplings per day) and analysed in the field, for temperature, salinity, $\mathrm{pH}$, oxygen and total ammonia nitrogen (TAN), and in the laboratory (Crema, France) for soluble nutrients (nitrites, nitrates, urea, phosphates) and particulate materials, total suspended solid (TSS), particulate organic matter (POM), chlorophyll $a$ and total pigments on fixed samples (same techniques of collecting and analysis as on the earlier study on wastewater retention lagoons). Chlorophyll $a$ and total pigments were measured by a fluorometric method (model 112, Sequoia Turner Inc., Mountain View, CA, USA) after extraction with $100 \%$ methanol [29]. Each hour during the test (1-2 October 1996), the volumes of foam condensates were measured in order to calculate the daily dissolved and particulate material trapped by one foam fractionation apparatus.

\subsection{Treatment by microalgae and bivalve filter feeders}

The first step in the treatment was carried out in an experimental microalgae reactor (figure 2), composed of a concrete raceway ( $48 \mathrm{~m}^{3}$ volume, $1.2 \mathrm{~m}$ depth), and 4 air diffusers to develop gentle aeration $(0.4 \mathrm{~L}$ air $\mathrm{L}^{-1}$ water $\cdot \mathrm{h}^{-1}$ ). The principle was to develop a continuous culture by stimulating native phytoplankton populations, preferentially diatoms. Domination by diatoms was insured by an optimal Si:P ratio (atom: atom) in the inflow and by an adapted water renewal rate. For the naturally occurring local species Skeletonema costatum, the optimal ratio of Si:P is 4 [13]. To correct the Si:P ratio, a continuous flow of sodium silicate solution in freshwater was added using a peristaltic pump (figure 2). The dilution rate adopted during the first summer experiment ( 24 days in JuneJuly 1996), presented here, was $70 \% \pm 10 \%$ per day. Experiments are in progress to optimize the rates of phosphate and TAN removal. The objective is not a total elimination of nitrogen nutrients but only a reduction of TAN concentrations to $0.5-1.0 \mathrm{mg} \mathrm{N} \cdot \mathrm{L}^{-1}$. Water temperature, $\mathrm{pH}$, dissolved oxygen and light irradiance at the water surface (sensor LI-192SA, LI-COR Inc., Lincoln, NE, USA) were recorded every $15 \mathrm{~min}$ on a data logger (model LI-1000, LI-COR Inc.) to determine total daily irradiance and mean daily temperature.

The second step in the water treatment was biological filtration of the microalgae produced by oysters (Crassostrea gigas). The principle has been elaborated and experimentally investigated in Israel [19-21] in pond rearing of sea bream (Sparus aurata). Our objective has been only to adapt and calibrate existing processes and models to reach the desired rate of microalgal removal, using oysters $[2,3]$ or other bivalve species. Lefebvre (unpubl. data) carried out preliminary tests on oysters in $1-\mathrm{m}^{3}$ fibreglass tanks in summer (August 1996) and 0.4- $\mathrm{m}^{3}$ tanks in winter (February 1997), with different stocking densities of oysters (between 58 and $1530 \mathrm{mg}$ dry matter $\cdot \mathrm{L}^{-1}$, table $V$ ) and a constant inflow of effluent treated using the microalgal reactor $\left(0.35 \mathrm{~g} \cdot \mathrm{d}^{-1}\right.$ of total pigments $)$. Aerated tanks were covered with a black plastic cover $(100 \%$ shade) to eliminate phytoplankton production. 


\section{GROSS EFFLUENT INFLOW HIGH NUTRIENT CONCENTRATION LOW DIATOM CELL NUMBER}

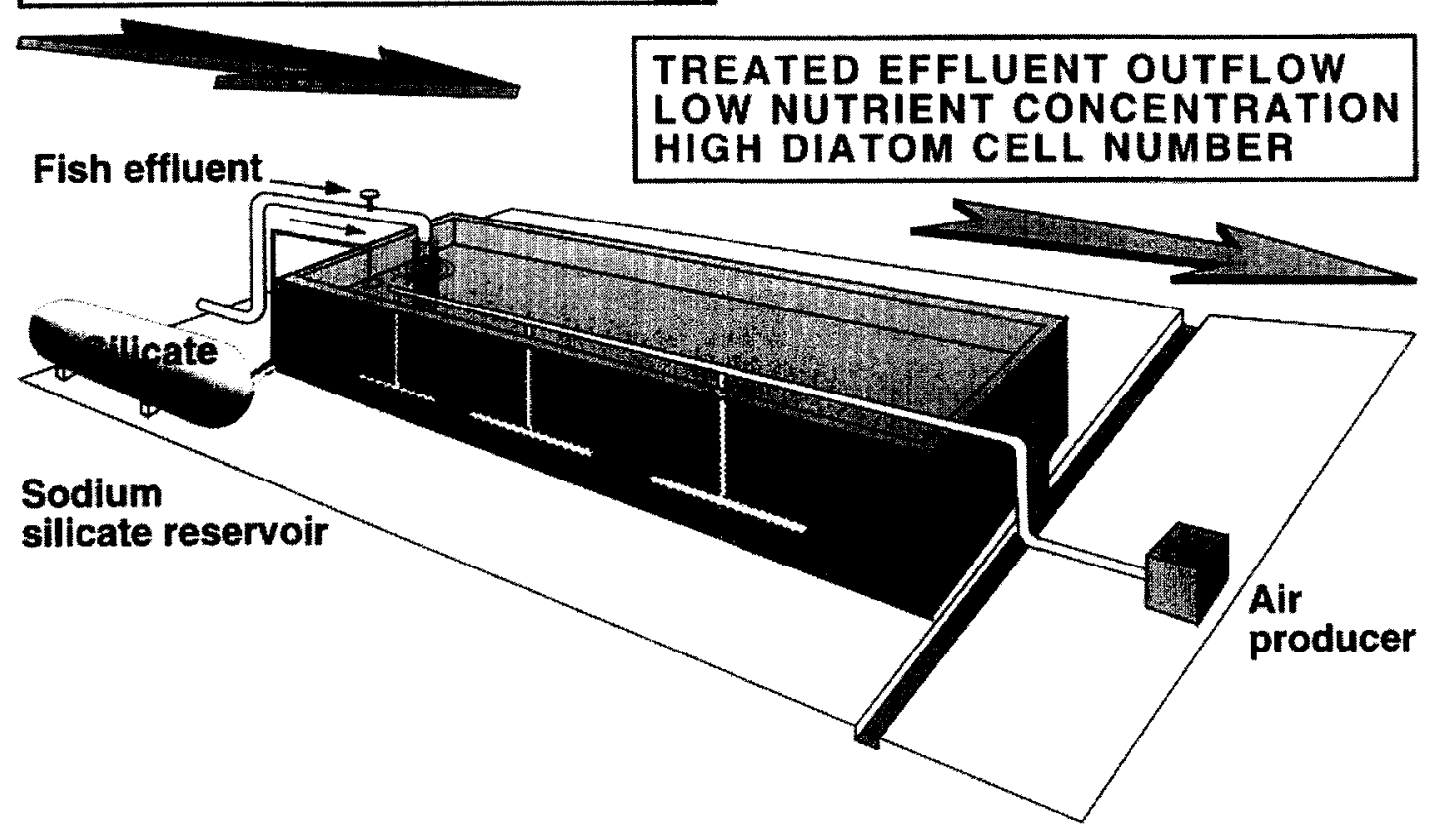

Figure 2. View of the microalgae reactor equipped with silicate injection to develop a preferential orientation toward diatoms (graph: Y. Descatoire, Crema, 1997).

\section{RESULTS}

\subsection{Treatment by wastewater retention lagoon}

The mean water quality, entering in the wastewater retention lagoon (fish-tank water) and leaving it, is described (table II) for variable- (V-) and constant(C-) level retention systems in summer (year 1996). For V-system (farm 1), an improvement in quality was observed: $\mathrm{pH}(+0.2$ unit) and dissolved oxygen $\left(+0.2 \mathrm{mg} \cdot \mathrm{L}^{-1}\right)$ increased, volatile suspended solid
(VSS, $-20 \%)$, nitrites $(-50 \%)$, nitrates $(-27 \%)$, phosphates $(-52 \%)$ decreased. Water quality deterioration appeared in total ammonia nitrogen (TAN, $+9 \%$ ) and total suspended solid (TSS, $+60 \%$ ). Nevertheless, all data remained below the maximum levels recommended [4, 14]. For fish tank waters in farm 2, mean effluent loads were higher than for farm 1 for TAN, phosphates, TSS and VSS (table II). C-system (farm 2) gave a deterioration in water quality with an increase

Table II. Water quality before and after retention in wastewater retention lagoons (WWRL), mean concentrations of oxygen ( $\mathrm{mg} \cdot \mathrm{L}^{-1}$ ), total ammonia nitrogen (TAN, $\mathrm{mg} \mathrm{N}^{-1}$ ), nitrites and nitrates $\left(\mathrm{mg} \mathrm{N}^{-1} \mathrm{~L}^{-1}\right.$ ), phosphates (mg P. $\left.\mathrm{L}^{-1}\right)$, total suspended solids (TSS, $\mathrm{mg} \cdot \mathrm{L}^{-1} \mathrm{dry}$ weight), volatile suspended solids (VSS, $\mathrm{mg} \cdot \mathrm{L}^{-1}$ dry weight) and $\mathrm{pH}$.

\begin{tabular}{|c|c|c|c|c|c|c|}
\hline \multirow[t]{3}{*}{ Parameters } & \multirow{2}{*}{\multicolumn{2}{|c|}{$\frac{\text { Farm } 1}{\text { V-WWRL }}$}} & \multirow{2}{*}{\multicolumn{2}{|c|}{$\begin{array}{c}\text { Farm } 2 \\
\text { C-WWRL }\end{array}$}} & \multicolumn{2}{|c|}{ Water quality criteria } \\
\hline & & & & & \multirow[t]{2}{*}{ Boyd $[4] *$} & \multirow{2}{*}{ Malone [14] ** } \\
\hline & Inlet & Outlet & Inlet & Outlet & & \\
\hline$\overline{\mathrm{pH}}$ & 7.5 & 7.7 & 7.1 & 7.3 & $6.0-8.5$ & $>7.0$ \\
\hline Oxygen & 5.0 & 5.7 & 5.5 & 7.0 & $>5.0$ & $>5.0$ \\
\hline TAN & 0.75 & 0.82 & 1.50 & 1.10 & 1.77 & $<1.0$ \\
\hline Nitrite & 0.10 & 0.05 & 0.12 & 0.17 & 0.83 & $<1.0$ \\
\hline Nitrate & 1.10 & 0.80 & 0.15 & 0.20 & 16.90 & $<200$ \\
\hline Phosphate & 0.25 & 0.12 & 0.40 & 0.3 & 0.17 & \\
\hline TSS & 10.0 & 16.0 & 47.0 & 30.0 & 30.0 & $<15$ \\
\hline VSS & 5.0 & 4.0 & 10.0 & 10.0 & & \\
\hline
\end{tabular}

* Recommended effluent concentration limits by US Environmental Protection Agency.

** Upper limit for recirculating systems of marine growout ('mesotrophic system')

Sampling days: Farm 1 - May 29-30, July 11-12 1996; Farm 2- June 18, July 4 and 19, August 21996. 
in nitrites $(+42 \%)$ and nitrates $(+33 \%)$, but removed TSS $(-36 \%)$, TAN $(-27 \%)$ and phosphates $(-25 \%)$ considerably.

In farm 2, during the two-year observation period, four water flow rates were investigated, depending on the time of year and on fish biomass. It is interesting to note that TSS removal by constant level retention lagoon, expressed as $\mathrm{kg} \cdot \mathrm{ha}^{-1} \cdot \mathrm{d}^{-1}$, did not change very much within a $30-4510^{3} \mathrm{~m}^{3} \cdot \mathrm{ha}^{-1} \cdot \mathrm{d}^{-1}$ flow rate (figure 3). Removal of TSS was about 1 metric ton $\cdot \mathrm{ha}^{-1} \cdot \mathrm{d}^{-1}$ of dry matter, i.e. $100 \mathrm{~g} \cdot \mathrm{m}^{-2} \cdot \mathrm{d}^{-1}$.

\subsection{Treatment by foam fractionation}

Under the experimental conditions described in 'Material and Methods', the tested foam fractionator produced $60 \mathrm{~L} \cdot \mathrm{h}^{-1}$ of foam condensate. We calculated the enrichment factor ( $f$ ) between the culture water (inlet) and the foam condensate, for each water parameter (figure 4). The foam fractionation apparatus (FFA) was good at trapping dissolved materials, particularly (i) organic forms, such as urea ( $f=12.8)$, and (ii) mineral forms, such as phosphates ( $f=5.1$, and total

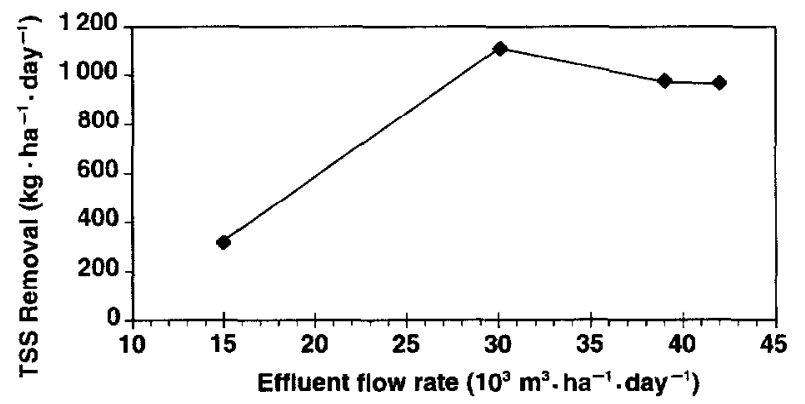

Figure 3. Daily total suspended solids removal versus effluent flow rate in the wastewater retention lagoon (farm 2), kept at a constant water level.

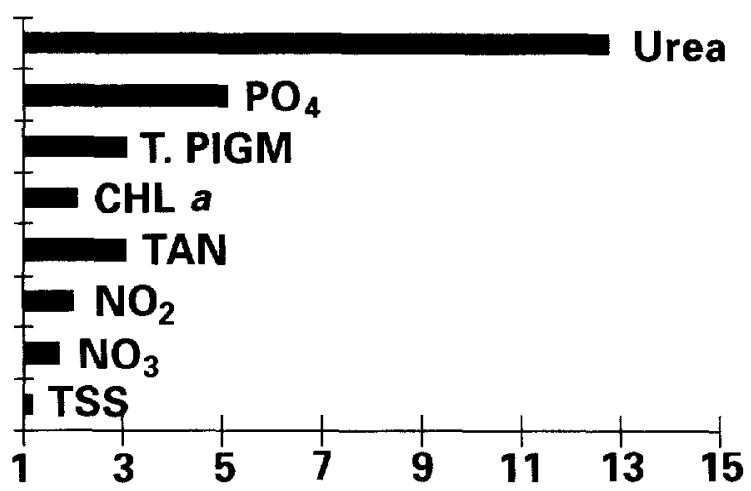

Figure 4. Enrichment factor in the foam condensate compared with untreated water crossing the foam fractionator for different water parameters.

Aquat. Living Resour. 11 (4) (1998) ammonia nitrogen $(f=3.1)$, as previously described [6, $12,23,26,28]$. As Lawson and Wheaton [12] noted, however, many parameters can modify the efficiency of a foam fractionator: water quality (temperature, viscosity, surface tension, $\mathrm{pH}$, organic compounds, etc.) as well as the characteristics of the fractionator itself (dimensions, liquid and gas flow rates, bubble size, etc.). Concentrations of dissolved organic and inorganic compounds that crossed the FFA in our situation (extensive aquaculture), were low (table $I I I$ ) compared with those under conditions of intensive fish culture. The preceding results can not be extrapolated to intensive fish farm effluents; this explains why we intend to start a series of tests in 1998 to determine the removal efficiency in farm 1 and farm 2 effluents.

Table III. Mean water quality that crossed (inlet and outlet) the foam fractionation apparatus (FFA) implanted in the Italian extensive fish farm, and water quality of the foam condensate. TAN: total ammonia nitrogen; TSS: total suspended solid; VSS: volatile suspended solid.

\begin{tabular}{lccc}
\hline Parameters & $\begin{array}{c}\text { Water } \\
\text { inlet }\end{array}$ & $\begin{array}{c}\text { Water } \\
\text { outlet }\end{array}$ & $\begin{array}{c}\text { Foam } \\
\text { condensate }\end{array}$ \\
\hline Temperature $\left({ }^{\circ} \mathrm{C}\right)$ & 19.3 & 19.3 & 19.3 \\
Salinity & 24.0 & 24.0 & 23.8 \\
pH & 7.88 & 7.87 & 7.90 \\
Oxygen $\left(\mathrm{mg} \cdot \mathrm{L}^{-1}\right)$ & 7.0 & 7.1 & 7.8 \\
TAN $\left(\mathrm{mg} \mathrm{N} \cdot \mathrm{L}^{-1}\right)$ & 0.18 & 0.18 & 0.59 \\
Nitrite $\left(\mathrm{mg} \mathrm{N} \cdot \mathrm{L}^{-1}\right)$ & 0.03 & 0.03 & 0.05 \\
Nitrate $\left(\mathrm{mg} \mathrm{N} \cdot \mathrm{L}^{-1}\right)$ & 0.03 & 0.03 & 0.20 \\
Urea $\left(\mathrm{mg} \mathrm{N} \cdot \mathrm{L}^{-1}\right)$ & 0.04 & 0.04 & 0.55 \\
Phosphate $\left(\mathrm{mg} \mathrm{P} \cdot \mathrm{L}^{-1}\right)$ & 0.04 & 0.04 & 0.21 \\
Silicate $\left(\mathrm{mg} \mathrm{Si} \cdot \mathrm{L}^{-1}\right)$ & 0.24 & 0.20 & 0.49 \\
Optical density $(680 \mathrm{~nm})$ & 0.006 & 0.005 & 0.046 \\
Total pigments $\left(\mu \mathrm{gg} \cdot \mathrm{L}^{-1}\right)$ & 3.4 & 3.5 & 10.4 \\
Chlorophyll $a\left(\mu \mathrm{g} \cdot \mathrm{L}^{-1}\right)$ & 1.8 & 1.9 & 3.8 \\
TSS $\left(\mathrm{mg} \cdot \mathrm{L}^{-1}\right)$ & 8.2 & 7.5 & 9.8 \\
VSS $\left(\mathrm{mg} \cdot \mathrm{L}^{-1}\right)$ & 2.6 & 2.2 & 2.9 \\
\hline
\end{tabular}

* cell length: $25 \mathrm{~mm}$; Sampling days: October 1-2 1996, two samplings per day.

An increment in phytoplankton biomass indicators (optical density at $680 \mathrm{~nm}$, total pigments, chlorophyll $a$ ) was found in the foam condensate (figure 4 and table III). This confirms that FFA is also efficient in removing small particulate materials $(<8 \mu \mathrm{m}$, according to Chen et al. [5]) but can not remove TSS, which is essentially constituted of large particles (faeces, feed). After one passage through the foam fractionator, the dissolved material removal was low, $0.8 \mathrm{~g} \mathrm{~N}$-urea $\cdot \mathrm{d}^{-1}$ for a daily flow of $256 \mathrm{~g} \mathrm{~N}$-urea, i.e. only $0.3 \%$, and on phosphates $0.31 \mathrm{~g} \mathrm{P}^{-\mathrm{PO}_{4}} \cdot \mathrm{d}^{-1}$ for a daily flow of $110 \mathrm{~g} \mathrm{P}-\mathrm{PO}_{4}$, i.e. only $0.12 \%$.

\subsection{Treatment by microalgae and bivalve filter feeders}

During the experiment on treatment with the microalgal reactor (summer 1996), the environmental conditions for phytoplankton growth were: mean water temperature of $21.5^{\circ} \mathrm{C}$ (min.-max.: 18-24); mean 
Table IV. Mean concentrations of nitrogen (TAN, mg N. $\mathrm{L}^{-1}$ ), phosphorous ( $\mathrm{mg} \mathrm{P} \cdot \mathrm{L}^{-1}$ ), silica $\left(\mathrm{mg} \mathrm{Si} \cdot \mathrm{L}^{-1}\right)$, total pigments $\left(\mu \mathrm{g} \cdot \mathrm{L}^{-1}\right)$ and volatile suspended solids (VSS, $\mathrm{mg} \cdot \mathrm{L}^{-1}$ ) in the fish effluent entering the experimental microalgae reactor, and daily quantity per volume unit of reactor $\left(\mathrm{g} \cdot \mathrm{d}^{-1} \cdot \mathrm{m}^{-3}\right.$ of reactor) of N, P and Si entering the reactor and removed by the microalgat treatment. Sampling days: 24 days in June-July 1996, one sampling per day at $14: 00 \mathrm{~h}$.

\begin{tabular}{lccccr}
\hline & TAN-N & $\mathrm{PO}_{4}-\mathrm{P}$ & $\mathrm{SiO}_{3}$-Si & Pigments & VSS \\
\hline Fish effluent quality & 1.85 & 0.35 & 1.59 & 0.02 & 12.56 \\
Inflow (g.day ${ }^{-1}$ ) & 1.27 & 0.24 & 1.09 & 0.01 & 8.61 \\
Removal (g.day ${ }^{-1}$ ) & 0.85 & 0.11 & 0.55 & -0.14 & -4.15 \\
Removal (\% of inflow) & 67.0 & 46.6 & 50.2 & -1139 & -48.2 \\
\hline
\end{tabular}

Table V. Experimental conditions and phytoplankton removal expressed as volatile suspended solids (VSS) and total pigments, in an oyster 'filter' tested in summer and winter. VSS: volatile suspended solid.

\begin{tabular}{|c|c|c|c|c|}
\hline & \multicolumn{2}{|c|}{ Summer (Aug. 96) } & \multicolumn{2}{|c|}{ Winter (Feb. 97) } \\
\hline Number of experimental days & \multirow{2}{*}{\multicolumn{2}{|c|}{$\begin{array}{c}20 \\
21.5(19.8-23.8)\end{array}$}} & \multirow{2}{*}{\multicolumn{2}{|c|}{$\begin{array}{c}10 \\
13.4(13.0-13.9)\end{array}$}} \\
\hline Temperature (min.-max.) $\left({ }^{\circ} \mathrm{C}\right)$ & & & & \\
\hline Oyster loading in tanks $\left(\mathrm{mg} \cdot \mathrm{L}^{-1}\right)^{a}$ & 58 & 424 & 500 & 1530 \\
\hline Water renewal rate in tanks (day ${ }^{1}$ ) & 1.2 & 1.2 & 6.2 & 6.5 \\
\hline Mean daily VSS inflow $\left(\mathrm{g} \cdot \mathrm{day}^{-1}\right)$ & 20.0 & 20.0 & 24.4 & 26.0 \\
\hline Mean daily Total pigments & 0.35 & 0.35 & 0.35 & 0.35 \\
\hline Mean VSS removal $(\%)$ & $\varepsilon$ & 33 & n.m. & n.m. \\
\hline Mean Total pigments removal ( $\%$ ) & $\varepsilon$ & 50 & 83 & 95 \\
\hline Oyster loading per daily water renewal $\left(\mathrm{mg} \cdot \mathrm{L}^{-1} \cdot \mathrm{day}^{-1}\right)$ & 48 & 350 & 81 & 235 \\
\hline Oyster survival $(\%)$ & 15 & 92 & 100 & 100 \\
\hline
\end{tabular}

E: near zero; n.m.: not measured; :

salinity of $34.8 \mathrm{~g} \cdot \mathrm{kg}^{-1}$ (min.-max.: 34.2-35.4); mean total daily irradiance of $50 \mathrm{~mol} \cdot \mathrm{m}^{-2} \cdot \mathrm{d}^{-1}$ (min.-max.: $24-63$ ); $\mathrm{pH}$ range $7.6-8.6$; oxygen saturation range $99-166 \%$. In the fish effluent (inlet to reactor), the mean concentration of nutrients was high and phytoplankton biomass (expressed as total pigments or VSS) was low. After treatment, the concentrations were inversed, with a high level of microalgae and a low level of inorganic nutrients (table $I V$ ). On average, more than $50 \%$ of the nutrients (N-TAN, P-PO, $\mathrm{Si}-\mathrm{SiO}_{3}$ ) were removed. The diatom $\mathrm{S}$. costatum dominated the algal population $(90 \%)$.

Microalgal removal by oysters (Crassostrea gigas) was efficient throughout the year (table $V$ ), except during gametogenesis when food availability has to be considerably reduced to improve oyster survival. We found a maximum removal of $100 \%$ of the microalgae in winter and $92 \%$ in summer.

\section{DISCUSSION}

Different means of treating effluents of grow-out land-based fish farms in open-air systems have been studied. For extensive aquaculture, aeration and foam fractionation are efficient enough. The foam fractionation apparatus developed by Valle Figheri could be very useful in revivifying dead areas of ponds and lagoons, to detoxify polluted waters and to promote the circulation of oxygenated waters in still-water reservoirs. The low removal efficiency of foam fractionators can be improved in closed recirculation systems by inloop circulation as recommended by Dwivedy [8].
For intensive systems, only one of the different treatment systems tested is not efficient enough. Table VI summarizes the removal efficiency of each treatment studied for the principal water parameters. It can be seen that each treatment is efficient for a different parameter: retention lagoon for particulate material, foam fractionation for dissolved organic material, microalgal reactor combined with bivalve filtration on mineral nutrients and phytoplankton. Our view, supported by the above results, is that to develop cfficient open-air treatment of intensive marine aquaculture effluents, suitable combination of these water treatments will ensure fully efficient purification. Research to develop integrated open-air water treatment of landbased marine fish farms in intensive systems will have to consist of a series of experiments coupling various treatınents. In particular, such investigations will have to determine precisely where it is best to use a foam fractionator in the treatment chain. A possible integrated treatment is proposed (figure 5). It is theoreti-

Table VI. Semi-quantitative evaluation of removal efficiency, for each treatment studied, on different water parameters: total suspended solids (TSS), chlorophyll a (Chl), total ammonia nitrogen (TAN), dissolved organic matter (DOM, i.e. urea, amino-acids, proteins, etc.), orthophosphates $\left(\mathrm{PO}_{4}\right)$.

\begin{tabular}{lccccc}
\hline Treatment & TSS & Chl & TAN & DOM & $\mathrm{PO}_{4}$ \\
\hline Retention lagoon & +++ & $\mathrm{o} /--$ & $\mathrm{o} /+$ & 0 & + \\
Foam fractionation & + & + & + & +++ & + \\
Microalgae reactor & - & -- & +++ & $0 /-$ & ++ \\
Bivalve filter & ++ & +++ & $\mathrm{o} /-$ & - & 0 \\
\hline
\end{tabular}

+++: high removal; ++: medium removal; +: low removal; o: no removal; --- : high production; --: medium production; -: low production. 


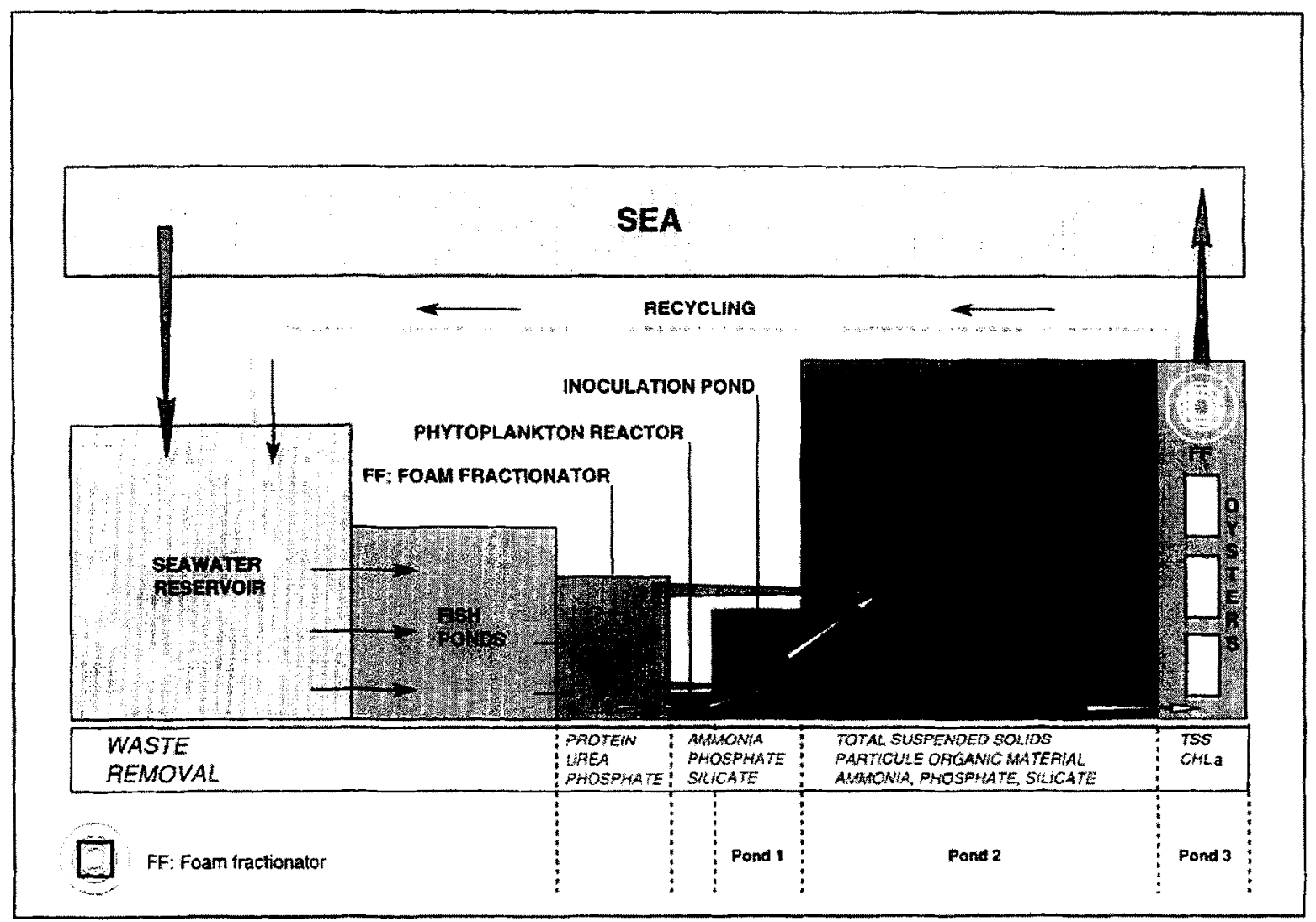

Figure 5. Schematic and theoretical representation of an outdoor integrated treatment for intensive marine fish farms, coupling foam fractionation, elimination of dissolved material by microalgal production (ammonia and phosphates), and suspended solids by retention lagoon and biofiltration by oysters (graph: Y. Descatoire, Crema, 1997).

cally correct for the farms studied, with a sun-shade over the fish-ponds limiting solar irradiance, and consequently primary production at this level. Foam fractionators are positioned first in the chain, to reduce dissolved organic material before the natural action of marine bacteria degrades proteins and amino acids into ammonia-nitrogen. Secondly, in a more downstream part of the effluent flow, an intensive microalgal reactor (continuous culture) in concrete tanks, with input of silicate if necessary (to correct the Si:P ratio), develops a diatom culture. This diatom culture could be transferred as an inoculum when in exponential phase to a bigger microalgal treatment pond (pond 1) aerated to mix and desaturate the waters. Research must be carried out to determine the optimum proportion of inoculum water flow to fish effluent flow entering the second microalgal reactor to develop the diatom mass production. The principal flow of the effluent could then be led to a second pond (pond 2), identical with the above wastewater retention lagoon, at constant level, for removal of faeces, unconsumed feed and inorganic particles as in farm 2. The water outflow from pond 1 , rich in phytoplankton (diatoms and other natural populations) could also be used to inoculate the wastewater retention lagoon (pond 2). A final pond (pond 3) could be used as a bivalve filter to eliminate phytoplankton. If the efficiency of this strategy of ponds 'in series' is confirmed, the aim of reducing the treatment costs by using earthen ponds, which are cheaper that concrete ponds, to produce the major part of the phytoplankton would be realized.

\section{Acknowledgements}

The work was presented at the 3rd Nutritional Strategies and Management of Aquaculture Waste (NSMAW) International Symposium in Vila Real, Portugal (2-4 October 1997). It was supported in part by a grant from the 'Conseil général de la Charente-Maritime'. The authors also acknowledge the following individuals for their co-operation and for facilitating the studies in private fish farms: Dr Stefano Cataudella of the University of Tor Vergata, Roma and Dr Andrea Fusari, biologist at the Valle 
Figheri farm, Campania Lupia, Padova, Italy; André Zwaga, technical director, and Bernard Houin manager of the 'Ferme Marine des Baleines', St-Clément-des-Baleines, France; Dominique Duval and Patrick Ernoult, managers of the 'Société Aquacole de l'île de Ré', Loix en Ré, France. The authors would like to thank I. Jenkinson for his helpful comments.

\section{REFERENCES}

[1] Barg U.C., Lignes directrices pour la promotion de la gestion de l'environnement dans le développement de l'aquaculture côtière, FAO Doc. Techn. Pêches, Rome, $328,1995,133 \mathrm{p}$.

[2] Barillé L., Héral M., Barillé-Boyer A.L., Modélisation de l'écophysiologie de l'huître Crassostrea gigas dans un environnement estuarien, Aquat. Living Resour 10 (1997) 31-48.

[3] Bougrier S., Geairon P., Deslous-Paoli J.M., Bacher C., Jonquières G., Allometric relationships and effects of temperature on clearance and oxygen consumption rates of Crassostrea gigas (Thunberg), Aquaculture 134 (1995) 143-154.

[4] Boyd C.E., Source water, soil and water quality impacts on sustainability in aquaculture, in: Bardach J., Corbin J., Duncan B. (Eds.), Sustainable aquaculture 95, Pacon, Honolulu, Hawaii, 1995, pp. 24--33.

[5] Chen S., Timmons M.B., Bisogni Jr J.J., Aneshansley D.J., Suspended solids removed by foam fractionation, Progress. Fish Cult. 555 (1992) 69-75.

[6] Chen S., Timmons M.B., Bisogni Jr J.J., Aneshansley D.J., Modeling surfactant removal in foam fractionation: I- Theoretical development, Aquac. Eng. 13 (1994) 163-181.

[7] Craggs R.J., Smith V.J., McAuley P.J., Wastewater nutrient removal by marine microalgae cultured under ambient conditions in mini-ponds, Water Sci. Technol. 31 (1995) 151-160.

[8] Dwivedy R.C., Removal of dissolved organics through foam fractionation in closed cycle systems for oyster production, Paper $n^{\circ} 73-561$, St Joseph, Michigan, 1973.

[9] Hussenot J., Brossard N., Lefebvre S., Benet A., Traitement par lagunage des effluents d'une pisciculture marine intensive : qualité des eaux et des sédiments, in: Amiard-Triquet C., Hamon T. (Eds.), La qualité de l'eau, université de Nantes, 1996, pp. 139-143.

[10] Hussenot J., Ximenes M.-C., Deslous-Paoli J.-M., Prou J., La place de l'aquaculture dans la valorisation multiusages des marais et étangs littoraux, C.R. Acad. Agric. Fr. 82 (1996) 87-99.

[11] Krom M.D., Neori A., Van Rijn J., Importance of water flow rate in controlling water quality processes in marine and freshwater fish ponds, Isr. J. Aquacult./ Bamidgeh 41 (1989) 23-33.

[12] Lawson T.B., Wheaton F.W., Removal of organics from fish culture water by foam fractionation, Proc. World Maric. Soc. 11 (1980) 128-134.

[13] Lefebvre S., Hussenot J., Brossard N., Water treatment of land-based fish farm effluents by outdoor culture of marine diatoms, J. Appl. Phycol. 8 (1996) 193-200.
[14] Malone R.F., DeLosReyes Jr A.A., Categories of recirculating aquaculture systems, in: Timmons M.B., Losordo T. (Eds.), Advances in aquacultural engineering, NRAES, Ithaca, 1997, pp. 197-208.

[15] Mires D., Aquaculture and the aquatic environment: mutual impact and preventive management, Isr. J. Aquacult/Bamidgeh 47 (1995)163-172.

[16] Rosenthal H., Aquaculture and the environment, World Aquac. 25 (1994) 4-11.

[17] Rosenthal H., Fish farm effluents and their control in EC countries: summary of a workshop, J. Appl. Ichthyol. 10 (1994) 215-224.

[18] Shpigel M., Blaylock R.A., The Pacific oyster, Crassostrea gigas, as a biological filter for marine fish aquaculture pond, Aquaculture 92 (1991) 187-197.

[19] Shpigel M., Lee J., Soohoo B., Fridman R., Gordin H., Use of effluent water from fish-ponds as a food source for the Pacific oyster, Crassostrea gigas Thunberg, Aquac. Fish. Manag. 24 (1993) 529-543.

[20] Shpigel M., Neori A., Popper D.M., Gordin H., A proposed model for "environmentally clean" land-based culture of fish, bivalves and seaweeds, Aquaculture 117 (1993) 115-128.

[21] Shpigel M., Gasith A., Kimmel E., A biomechanical filter for treating fish-pond effluents, Aquaculture 152 (1997) 103-117.

[22] Strickland J.D.H., Parsons T.R., A practical handbook of seawater analysis, Fish. Res. Board Can. Bull. 167 (1972) $310 \mathrm{p}$.

[23] Timmons M.B., Use of foam fractionators in aquaculture, in: Timmons M.B., Losordo T.M. (Eds.), Aquaculture water reuse systems: Engineering design and management, Elsevier, Amsterdam, 1994, pp. 247-279.

[24] Timmons M.B., Losordo T.M., Aquaculture water reuse systems: engineering design and management, Elsevier, Amsterdam, 1994, $333 \mathrm{p}$.

[25] Van Rijn J., 'The potential for integrated biological treatment systems in recirculating fish culture - a review, Aquaculture 139 (1996) 181-201.

[26] Weeks N.C., Timmons M.B., Chen S., Feasability of using foam fractionation for the removal of dissolved and suspended solids from fish culture water, Aquac. Eng. 11 (1992) 251-265.

[27] Wheaton F.W., Aquacultural engineering, Wiley, New York, 1977, 708 p.

[28] Wheaton F.W., Lawson T.B., Lomax K.M., Foam fractionation applied to aquacultural systems, Proc. World Maric. Soc. 10 (1979) 795-808.

[29] Yentsch C.S., Menzel D.W., A method for the determination of phytoplankton chlorophyll and phaeophytin by fluorescence, Deep Sea Res. 10 (1963) 221-231. 